University of Wollongong

Research Online

Faculty of Social Sciences - Papers (Archive) Faculty of Arts, Social Sciences \& Humanities

2018

International field placements: The models Australian social work

programmes are currently using

Mim Fox

University of Wollongong, mfox@uow.edu.au

Richard Hugman

University of New South Wales

Follow this and additional works at: https://ro.uow.edu.au/sspapers

Part of the Education Commons, and the Social and Behavioral Sciences Commons

Research Online is the open access institutional repository for the University of Wollongong. For further information contact the UOW Library: research-pubs@uow.edu.au 


\title{
International field placements: The models Australian social work programmes are currently using
}

\author{
Abstract \\ IInternational field placements have become increasingly common in Australian social work programmes. \\ This article looks at the models of organising international placements, in sending or receiving social \\ work students. Four such models are identified: informal linkages for individual students, linkages \\ between Australian social work programmes, formalised university to university agreements and \\ formalised university to agency agreements. Although there appears to be a preference for formalised \\ ongoing relationships between institutions in different countries, drawing on all four models as \\ appropriate and feasible will enable everyone involved in international placements to achieve the most \\ positive practice possible. \\ Disciplines \\ Education | Social and Behavioral Sciences

\section{Publication Details} \\ Fox, M. \& Hugman, R. (2019). International field placements: The models Australian social work \\ programmes are currently using. International Social Work,62 (5), 1-13.
}




\title{
International field placements: the models Australian social work programs are currently using
}

Dr Mim Fox

mfox@uow.edu.au

University of Wollongong, Australia

Professor Richard Hugman

r.hugman@unsw.edu.au

University of New South Wales, Australia

\begin{abstract}
International field placements have become increasingly common in Australian social work programs. This article looks at the models of organising international placements, in sending or receiving social work student. Four such models are identified: informal linkages for individual students; linkages between Australian social work programs; formalised university to university agreements; and formalised university to agency agreements. Although there appears to be a preference for formalized ongoing relationships between institutions in different countries, drawing on all four models as appropriate and feasible will enable everyone involved in international placements to achieve the most positive practice possible.
\end{abstract}

\section{Introduction}

Social work programs throughout Australia currently provide international field placements as an inclusion in their curriculum offerings (Crisp, 2017), an international practice teaching experience that resonates with social work programs around the world (Matthew \& Lough, 2016). This inclusion stems from a history of international collaboration within the social work profession (Healy, 2008) and is reinforced by more recent critical discussions of social work practice and globalisation (Dominelli, 2014; Gray \& Fook, 2004; Hugman, 2010; Lyons, Manion \& Carlsen, 2006; Sewpaul \& Jones, 2004). In 
particular, questions have increasingly been raised in the last decade about how international placements are organised, focusing on whether they ignore or challenge historically unequal relationships between countries of the global South and North (Gray, 2005; Wehbi, 2009; Hugman, 2010; Ashancaen Crabtree et al., 2014).

The inclusion of international field placements is enhanced through an agenda of internationalisation occurring within Australian universities (Bell et al., 2017; Crisp, 2017), paralled by an increased interest among the student body (Small et al., 2015). Each international field placement comes with individual expectations by all parties involved, including home and host universities, students and agency field educators or supervisors (Mathiesen \& Lager, 2007). The negotiation of these expectations, as well as the general development, organisation and educational support provided to these placements is resource heavy and in Australia, relies strongly on institutional support (Brydon et al., 2015; Crisp, 2017).

\section{Background to the research}

\section{Existing literature on models}

Despite an increase in literature concerning the proliferation of international field placements in social work education globally (beginning, for example, with Healy et al., 2003), there is as yet no comprehensive overview of potential models that universities or international agencies can and do employ. The recent published literature regarding Australian social work programs undertaking international field placements discusses either the quality of the experience itself (Cleak and Fox, 2011; Fox, 2016, 2017; Garrity, 2011; Nickson et al., 2009), or the levels of educational support required by the universities (Garrity, 2011; Bell \& Anscombe, 2013).

Internationally, and in Australia, the literature regarding models of short-term study abroad trips has increased over recent years, providing a greater understanding of the learning and insights that students can gain from an 
international experience (Bell et al., 2017; Barlow, 2007; Pettys et al., 2005; Roholt \& Fisher, 2013). In addition, this literature has assisted in providing insight into student motivations and the relevance of individual skill sets to the success of the placement (Crisp, 2009; Rai, 2004; Wehbi, 2009).

Whilst there is no overview of models in the literature, the international and Australian literature identifies specific models being used, albeit without comparison (Coventry \& Grace, 2013; Panos et al., 2004; Pawar et al., 2004; Plummer \& Nyang'au, 2009). Arguments about best practice principles in social work education have included international field placements. Some writers emphasise practical issues, for example looking at patterns of communication between the home and hosting universities (Mathiesen \& Lager, 2007). Others examine critical debates about the ethical relationship of the global South and North has led to some researchers arguing for models that are based explicitly on anti-colonial and decolonising principles (Rotabi et al., 2006; Wehbi, 2009, 2011; Aschencaen Crabtreee et al., 2014). Although based on different perspectives, both approaches seek to develop ideas about practice in a field where subjectivity and often circumstance are what enables an international field placement to occur. From these debates principles for developing appropriate models can begin to be overtly discussed (Mathiesen \& Lager, 2007; Matthew \& Lough, 2016).

Given the increasing number of social work programs offering students international field placements as an option and the lack of guiding literature on best practice in this area, this article presents a series of models of the ways international field placements are currently organised in Australia. The aim in presenting these models is to discuss the many issues that encourage successful learning experiences for students, thereby providing a guide for those programs interested in exploring potential options for their own students, or for social work practitioners who have been approached to supervise these placements in their agencies.

\section{Internationalisation of universities}


The objective of internationalization has become prevalent in universities around the world, including in Australia. For social work programs international field placements provide a crucial link between the underlying principles of international social work practice and the demands of an internationalised educational environment.

In practical terms, there is an increase in awareness by universities regarding the safety and risk that students undertake when travelling across the globe (Bettman \& Prospero, 2015). Risk management and duty of care are therefore concepts that underpin the development and organisation of international field placements. Although duty of care is a phrase familiar to social work practice, in the international field placement context this refers to the sense of responsibility that university staff and agency field educators feel towards the students that they either send or host (Fox, 2017). While this can be viewed as a natural extension of the interpersonal dynamic, there is a concern that the care can become either paternal, or parochial, in nature (Tronto, 2012). This raises the question of how an appropriate level of care and concern for the remote student can be managed in ways that is respectful of both the students capacities and the contribution of the receiving/host colleagues in the other country.

\section{Including the international field placement in curriculum}

Educationally, the benefits of international experience in social work education come from the potential development by students of cross-cultural capacities and anti-colonialist practice in an interdependent globalized world (Gray, 2005; Wehbi, 2011). Challenges to ethnocentrism are crucial in this process (Engstrom \& Jones, 2007). International comparison, particularly of social welfare systems, is also advocated for as crucial to this learning (Healy, 2008), with an emphasis on the students' learning processes becoming "more personal and pertinent, and the foreign become[ing] more familiar" (Hawkins \& Knox, 2014, p. 249). 
International field placements can be instrumental in preparing students for a future career in international practice, providing them with critical crosscultural learning experiences, different systems of welfare and different perspectives on addressing social issues, as well as providing them with valuable overseas experience, often a prerequisite to securing a professional position upon graduation (Healy, 2008; Wehbi, 2011). In addition, in countries where the possibility of cultural and ethnic diversity in local field placements is minimal, the provision of international field placements offers social work students an opportunity to develop skills and understanding that are often not possible in a local field placement (Rotabi et al., 2006; Saito \& Johns, 2009).

Yet, despite the university initiating an environment conducive to international partnerships, and despite the benefits to the student of including international field placements in the social work curriculum, support for international field placements by social work programs can be variable. The decision to offer international placements is often dependent on a practical distribution of financial and human resources, given the time university staff expend in organising and supporting an international field placement (Fox, 2017). In this context the decision to include international field placements in the social work program is often made in the absence of knowledge and critical practice, and is heavily reliant on the preferences of key social work program staff.

\section{Methodology}

Ethics approval for this study was gained from the University of New South Wales Human Research Ethics Committee in 2009 and data analysis was completed in 2012. This was an exploratory qualitative study, which examined the overarching research question 'what extent did an international field placement equip social work students to practise in the field of international social work?' 
An initial survey was sent to those employed by qualifying social work programs at Australian universities, purposively sampled to identify potential respondents in field education roles. The survey contained both quantitative (demographic) and qualitative (narrative) questions regarding the experience of international field placements. Of the 28 surveys sent to social work programs across Australia (total social work programs at time of data collection), 22 (79\%) responses were received, with a total of 15 programs indicating that they either sent Australian social work students to other countries for field placements, received international students from overseas universities to undertake an international field placement, or participated in both aspects.

Survey participants were then invited to self-enrol in the qualitative in-depth interviews, with additional snowball and purposive sampling being utilised to also include field educators and students. The findings reported on in this article specifically address data from these semi-structured in-depth interviews. Thus, the interview participants consisted of university staff working currently in field education provision in social work programs across Australia, field educators working in Australian agencies that had provided supervision for international students undertaking field placements over the previous 10 years, and former social work students that had completed international field placements as part of their qualifying social work program in the previous 10 years. The initial survey also helped to refine the interview guide and eventual questions posed.

Overall, 15 interviews with university field education staff were conducted, 2 of which were from the same university. All Australian states and territories were represented in the interviews, with the same interview scheduled used in all instances. 10 interviews were conducted with former students. The students were sourced from 3 separate universities across Australia, with the majority having studied in New South Wales (7), a minority having studied in South Australia (2), and one participant having studied in Victoria. 9 interviews were conducted with field educators. All of the field educators interviewed had worked in agencies in Australia when they supervised international students 
from overseas universities on field placements in Australia. The findings in this article report on qualitative data collected from university staff members in the semi-structured interviews, with excerpts from agency field educators' interviews as appropriate.

\section{Findings}

Four models of international field placements were discussed by participants and identified as currently being used by social work programs and by agencies in Australia. All four models involve the sending or receiving of social work students, or were described as the structure within which Australian field educators were supervising students who had come to Australia. These models include formalised university to university agreements, formalised university to agency agreements, linkages between Australian social work programs, and informal linkages for the purpose of an individual student. The models are presented in the order of commonality across social work programs.

\section{Model 1- Informal linkages for the purpose of individual students}

Informal linkages is the most commonly used model for international field placements in social work programs across Australia. In this model the student either finds his or her own international field placement, and then gains university agreement and assistance in the organisation of it. Alternately the university finds a placement for a specific student and negotiates directly with the agency. In this model the home university does not hold a formalised agreement with either another university or an international agency. One university staff member describes a scenario where this was not the model they had wanted to utilize yet ultimately it was the most successful outcome for the student.

I had originally tried to organize for the student to enrol for the duration of her placement in a South African university [without success ...] 
Eventually I spoke fairly candidly with the student and said look, I'm not sure about what the politics of this are but I do have a contact in South Africa that is a social worker, I know the context, I know the sort of work you'd be doing (University Staff 1).

At some universities, this model replicates the model that they use to source and organise local field placements, on an individual basis dependent on the learning and practical needs of the student.

So my role has generally been finding out from the students who want to do it overseas, finding out what they are interested in and making the connections with [...] other universities in the other countries and then making connections with agencies (University Staff 2).

Even if the student initiates the process this does not exclude university staff from the organisation of the placement. In order for an international field placement to be formally recognised as a part of undergraduate training, it needs to adhere to the Australian Association of Social Workers requirements. These requirements include specified supervision hours and educational, or liaison, support from the home university (Fox, 2016). As described in the Australian literature, this informal linkages model is only successful with university planning for educational and liaison support (Nickson et al., 2011). At a pre-determined point the university field education staff take over the process to ensure the educational viability of the international placement. As one university staff member recounts, "it's up to them then to find an agency [...] We then take over the negotiation with that agency or the social work supervisor" (University Staff 8). In fact the incountry connections and networks that the students already have can be crucial in organising international field placements.

I usually ask the student if they've got any contacts or connections themselves with the possibility of a placement [...] If it's early enough, then we may be able to make contact and enquire about the viability of 
a placement and the nature of the agency and the placement opportunity (University Staff 12).

Ultimately the university field education staff member takes over the organisation and negotiation in this model when the need for educational viability and accreditation adherence needs to be determined. The location of appropriate social work supervision is the highest priority in this regard.

The onus is very much on the student to have the connections with a particular country or agency. We won't search for it, it's up to the student to have found a possible placement [...] they need to also have found a suitably qualified social work supervisor in the country and we've got some suggestions around [if] there isn't one in the agency that they're actually looking at (University Staff 3).

Informal linkages also emerge because the student has family members or personal contacts in the destination country, or because of student circumstances prior to the placement.

For the student who wanted to do the placement in Fiji it was because her son was there for twelve months as a volunteer and the agency was available [...], the same with the student who went to Vietnam. She was very keen to work on a particular project that was happening at this particular non-government organization [as] she'd been involved in writing the submission for the original project (University Staff 3).

Additionally, a student who speaks the local language can be useful in assisting the university staff member with the organisation and negotiation of the placement. As one university staff member recounts, "we had one student who wanted to go to Holland and she was actually from Holland herself [...] she speaks the language and is from there, and in some ways she was instrumental in facilitating the placement" (University Staff 9). 
Another university staff member describes their concern regarding informal linkages, indicating that the success of these informal arrangements is often dependent on other variables including the capacity of the student, and at times the location itself.

We can't manage every contingency but I really don't like the model of students finding their own placement [...] when they want to go to Europe and we've got a good student and if they want to go through all the hoops and set something up in a European country then fair enough, but if they want to go to South America or Africa or places like that $[\ldots]$ we have to say you can't find your own placement (University Staff 6).

Ultimately this university staff member needs to have been involved in the organisation of the international field placement to ensure its viability and the perceived safety of the student. The findings show that despite the extent of social work programs engaging in this model, informal linkages are not seen as equivalent to a formalised agreement and often are not the preference of the program. This model is usually undertaken in the absence of a formalised agreement, and is subject to variables such as a student's personal circumstances or a university staff member's individual initiative. However, these findings show that university field education staff maintain involvement in the organisation and negotiation of these placements to determine adherence to accreditation standards, as well as educational viability of the placement.

\section{Model 2- Linkages between Australian social work programs}

Linkages, both formal and informal, between Australian social work programs exist across the country for the purpose of international field placements. Participants describe the high level of support and professional validation that inter-university collegial partnerships can provide when they collaborate to organise an international field placement for a student. This model can 
minimise the time commitment that university field education staff make to the organisation of an international field placement, as well as increase the location opportunities for students. As one university staff member put it, "I think what we've done is to use our collegial networks to support each other with student placements and to broaden out the opportunities" (University Staff 4).

These collegial relationships can make what can potentially be organisationally challenging into an easier process for the university staff involved. One university staff member describes the collegial process as being straightforward, "I contacted [name of university staff at partner university] and I said we've got a student who wants to go, [academic] was willing to give me a contact in India who they'd used before" (University Staff 1). At times this can involve the complete delegation of responsibility for the teaching and learning of the student to the partner university. As another university staff member describes, "we didn't involve ourselves in preparation or debriefing or supervision, it was basically [name of university staff at partner university] did it all" (University Staff 4). The risk in this model is there can be tension between academic colleagues and programs where one has delegated responsibility for the students' assessment and at the end there is a disagreement as to the outcome of the students' progress.

In the end when there was questioning whether one of the students would pass, I went to the co-supervisor [agency field educator] and said, what's your assessment and she filled in her report and all the rest of it. So [name of university staff at partner university] was the only one who thought that one of them should fail, so it was bit nasty in the end (University Staff 4).

On the other hand, for universities who use this model regularly, it was spoken of so highly in the data that some university staff members suggested the establishment of an cross-country inter-university international field education unit. Two university staff members advocated for the combining of 
resources and idealistically overlooking differences in pedagogy for the sake of collaboration.

My sense is that international placements could be handled at a combined university level, that makes sense to me. It doesn't matter that we're pedagogically different or philosophically different (University Staff 5).

In fact, the proliferation of international field placements as an inclusion in social work education in Australia is such that collaboration and collegiality in social work education can be seen as a natural extension of professional practice.

I think there's a way that we could do that [international field placements] better, use our networks more collaboratively and not competitively. I don't buy the whole competition stuff to be honest. [Name of two universities] have both got our students needs met by being collaborative [...] so for me it's a quid pro quo, collegial, cooperative way to do it [...] Because it's one profession for heaven's sake (University Staff 4).

Linkages between social work programs are a common model being used in Australian universities for international field placements and overall are a source of collegiality amongst university staff. The risk present in this model is the detrimental effect on inter-university relationships if a clash in competing pedagogy occurs, with the impact ultimately being borne by the student's academic achievements. The lived experience of this model is so positive however, that participants in this study advocated for the establishment of a formalised version in an inter-university collaboration.

Model 3- Formalised university to university agreements 
Although not the most common, some university staff members discussed a model that included a formalised agreement between their university and another international university, with the specific aim of the provision of international field placements. These arrangements often develop out of informal, or opportunistic, academic collaborations and can either be part of a long term relationship or exist only for a single student placement. Often the arrangement is enshrined in a memorandum of understanding or other legal documentation as it is often a part of a broader university, or social work program, commitment to internationalisation or a global presence. At times the formalised agreement emerges organically out of academic international collaboration.

These were formed through contacts that different lecturers have made in the course of their work, at the conferences [...] one was formed because one of our lecturers was from India and returned to India and we maintained a relationship with her and through her with an organisation in India (University Staff 13).

Formal agreements can be reciprocal with students exchanging their study program regularly between the two universities. As one university staff member demonstrates, "last year we had two of their students come in second semester and similarly this year for the first semester we had someone come from Mumbai to here" (University Staff 5). These relationships can often include reciprocal educational support roles, or liaison, by the hosting university that can benefit the student experience. As another respondent put it, "they've sent students to us and I will find them an agency and then when we send students to them they will find them an agency" (University Staff 2).

Without the inclusion of educational or liaison support from the host university, risk management for the home university can become a concern in this model. Present in the data was an inequity in the different levels of either distance or local liaison support provided to students by different universities. University staff members highlighted the experiential difference for students 
when they do receive local liaison support, rather than distance support, with a sense of concern for students who do not have this available being evident.

We'd have liaison support organised for them but it'd be from an academic here so we'd be relying on Skype contact and phone calls and emails [...] it was very much offshore support, sometimes those placements were fraught for students so I still worry about them at times. Perhaps if there was onshore support, sort of local support for the student on that placement, maybe that would have made more of a difference to them being more supported (University Staff 7).

Duty of care is a concern for university field education staff and can present as the staff member feeling protective towards the student who is geographically distant from the home university. This protective, or paternal, feeling on the part of the university staff involved can then become validation for preferring this model to others.

We have a preference for being in a country where we can make a connection with another university [...] we need to make sure that someone in the country they're going to is able to just keep an eye on them [...] just because it's so far away [...] email is useful but having somebody close by in person is a nice safeguard (University Staff 2).

Having a formalised international relationship between universities can provide structural support for students whilst they're navigating a different system. Examples of structural support include immigration, housing, medical and financial assistance. This can be difficult for students without a local contact to assist them.

For students to be going overseas to different countries [they] might come up against stumbling blocks [such as visas and medical checks]. Where there's an exchange relationship [...] it makes it a bit clearer for migration that that's the purpose of their visit (University Staff 7). 
In this model students are often enrolled in their home universities' administrative system and yet are travelling to another university for a section of their degree. There can be a source of confusion for the student, requiring clarity and assistance in navigating these separate organisational systems, and at times differing pedagogies. As one university staff member describes,

The student's enrolled in the [field education] subject here but they're on exchange and that enrolment sits against the comparable subject over there. But in the end we return the result and the student completes the placement as per our educational requirements (University Staff 7).

The challenge for both the student and the home university is in ensuring there is cohesion between the organisational process, assessment requirements, and ultimately the underlying pedagogical framework. Without clarity and clear communication the expectations for the student can be confusing for all parties involved.

Even with a clear mandate from the university that supports international partnerships, this does not guarantee that international field placements will be supported, even when they had previously existed.

It was nearly a fifteen year partnership [...] we lost that exchange on practicum because the Dean and the School [at the Australian university] wanted a wider exchange and our university didn't agree to it. What a shame because the university sees itself as only having partnerships with the high profile universities so we lost that expertise (University Staff 14).

As previously discussed, the desire for an internationalized mandate exists in parallel with an increased awareness of the potential risk that students face when travelling globally. As one university staff member describes, there can be a very real threat to the student, staff members and university when risky 
situations occur. The impact of these experiences can be a hesitance from all parties in offering international field placements as an option.

My reservation stems from one girl going to Sri Lanka and she was there when the tsunami hit, so I'm now incredibly nervous [...] Then when the tsunami came in, I had no way of knowing whether she was ok or not, for about 3 weeks. I was sitting there thinking, 'I've sent this student to their doom' (University Staff 2).

This very real concern can mean that universities restrict and control which countries, and universities, they are willing to partner with.

Now the reason we have pulled back is to do with resources but also to do with risk management in the university. The international office, as a result of 9/11, has imposed some restrictions and has required us to concentrate on universities where we have prior exchange arrangements (University Staff 14).

In the risk adverse climate that universities currently operate in, the formalised agreement model can allow for delegated responsibility and a comforting sense of duty of care. This is most keenly experienced in the reciprocal relationship that incorporates educational and liaison support provided by the host university. However this inclusion does not always occur for students and cannot be assumed to be present. Regardless of this delineation of roles there exists in this model a need for educational and organisational cohesion and compatibility regarding student processes, placement assessment and international placement learning.

\section{Model 4- Formalised university to agency agreements}

Formalised agreements for the purpose of international field placements can exist between Australian universities and international agencies, and also between Australian agencies and international universities. One university in 
particular discussed this model in depth, while other universities referred to this model as being one of many models they were currently using. In addition 8 of the interviewed Australian field educators referred to having accepted students to supervise in this model after being approached directly from international universities. Formalised relationships between universities and international agencies can often develop into a long-term international partnership, bringing opportunities and improved reputation for the institution, staff and students. These formalised agreements can emerge from collaborative research that Australian academics are engaged with in overseas countries, and are in line with an international mandate, or mission statement, from the university. As one university staff member describes,

We were off [...], doing projects in Indonesia and Sri Lanka and different places and so from there we thought it would be good to have some students over there, so we started formally and then we developed a sort of five year plan and that was extended and we still send four students there a year (University Staff 6).

Australian university staff spoke of the inclusion of other academic activities for the faculty involved, such as guest lectureships, as being a clear benefit of this model. However, there is a substantial amount of continued effort and resourcing by Australian university staff in maintaining this model with international agencies. As University Staff 6 states, "I might do staff training and then do long liaisons and do some group stuff with the students to see how things are going" (University Staff 6). This input is required to maintain the relationship between organisations, and allows for a familiarity with the international agency and the field education staff that can develop over time. Ultimately this is of benefit to the student's learning experience. This input however is not always provided to field educators who take on the supervision of international students, leaving an inequity in educational and liaison support available.

We didn't have sufficient contact with the uni [university], they were very vague and when the placement started and there were issues it 
was very difficult to get anything useful from them. There was a bit of a language issue. [...] we found it incredibly difficult and incredibly frustrating to try and get from that uni [university] what they concretely wanted, because they were very vague, we couldn't get them to concretely say what the person needed to be able to achieve at the end (Field Educator 2).

Issues with pedagogical cohesion raised in previous models are reflected in this experience, as well as a need for support throughout the placement from the home university. Unfortunately, due to the geographical distance between the international agency and the home university it is not always possible to ensure educational support and liaison in this model. Australian social work programs still need to ensure they are meeting the minimum requirements for professional accreditation for placement supervision (AASW, 2010), making professional trust and relationships imperative in this model. This is a requirement that does not exist for Australian field educators supervising international students, yet many field educators still reported using the AASW guidelines for their supervision. The risk management concern that many universities experienced in previous models is evident in this model for field educators. As one field educator describes, without a hosting university involved in the international field placement, it is left to the agency to organise practical assistance, such as immigration visas, with the students.

DIMIA [Australian Department of Immigration, Multicultural \& Indigenous Affairs] had changed all the legislations and they had changed the visas so it was a nightmare [...] when we looked at the equivalent of that visa, that had then changed, there was no way that they [the Australian agency] would sign off on it because I think the reasons for that is that if one of the students went AWOL [missing] and stayed in Australia and shouldn't have, then we would be responsible for that person and of course the [Australian agency] wasn't able to sign off on that [...] in the end we just said well, they just need to go and organise tourist visas for themselves and then we will sort it when they come here $[. .$.$] they were very scared about that you see, so they$ 
chucked out most of their text books because they didn't think they should have text books because they would look like students (Field Educator 4).

The impact on the students in this example is fear at being in the country with an illegal status, a common fear held by peoples around the world. In this model the responsibility for alleviating this fear falls to the agency, an organization which ultimately has limited responsibility for the students well being. Field educators utilizing this model consistently provided examples where they were acting in the best interest of the students well being, despite the perceived lack of duty of care from the home university.

Formalized university to agency agreements is a model that requires a high level of resources, particularly financial and staffing, on the part of the Australian social work program and can be an area of inequity for the student in regards to educational and practical support. At the same time the benefits are such that a long term international partnership such as this can broaden the internationalization of the social work program involved by allowing for a range of academic activity beyond the scope of the international field placement and into the future for both staff and students.

\section{Discussion and Conclusion}

Australian social work programs use four different models when sending or receiving social work students on international field placements. These models are: informal linkages for individual students; linkages between Australian social work programs; formalised university to university agreements; and formalised university to agency agreements.

Despite their differences, there are points of commonality between the models that are helpful for considering positive practice. First, the university field education staff are always concerned with both the educational opportunities for students and student's wellbeing while undertaking placement. In addition, practice agencies providing the placements have a primary concern with the 
effect of international students on service users. Second, university staff are also often themselves interested in international social work and promoting critical practice, including cross-cultural awareness and respectfulness. This leads in many instances to them being willing to do more to enable such arrangements to occur than would be usual for local placements. Third, although the 'best practice' model is clearly that of formalized relationships between institutions in different countries, other influences such as university or agency policies, as well as student interest, often mean that the 'one-off' informal linkages model predominates. Nevertheless, the international social work principles of respect and responsibility are evident in the same way as in arrangements that are more formalized over time. Fourth, in all four models the availability of educational and liaison support, either long distance from the home university or explicitly delegated to a hosting university or agency can impact the wellbeing of the student and either reduce or exacerbate the concerns universities and hosting agencies have for the risk and safety of the students. Finally, open and ongoing communication between universities and agencies in different countries regarding expectations for pedagogy and organizational relationships allow for the student to engage fully in the international field placement, gaining the most they can from the educational and supervisory input.

In reality, 9 of the 15 social work programs involved in this study reported utilizing a combination of these models when organizing and negotiating international field placements. By doing so they are allowing for a flexibility in their offerings, encouraging the capacity to be student-led in their options whilst still maintaining local accreditation requirements. Through combining these models they are utilizing collegial relationships grounded in the principles of the social work profession, supporting international collaboration between agencies and universities, and working within an international agenda in the tertiary sector. By recognizing the different models and the commonalities between them it possible for universities to consider the opportunities and challenges that are involved in providing international field placements as these become more popular with students and more valued within university policies, as well as by some agencies. Although there 
appears to be a preference for formalized ongoing relationships between institutions in different countries, drawing on all four models as appropriate and feasible will enable everyone involved in international placements to achieve the most positive critical practice possible.

\section{References}

Aschencaen Crabtree S, Parker J, Azman A and Paul Carlo D (2014)

Epiphanies and learning in a postcolonial Malaysian context. International Social Work. 57(6): 618-629.

Australian Association of Social Workers (AASW) (2010) Australian Social Work Education and Accreditation Standards (ASWEAS), Canberra, AASW.

Barlow CA (2007) In the third space: a case study of Canadian students in a social work practicum in India. International Social Work 50(2): 243-254.

Bell K and Anscombe AW (Bill) (2013). International field experience in social work: outcomes of a short-term study abroad programme to India. Social Work Education: The International Journal 32(8): 1032-1047.

Bell K, Moorhead B and Boetto H (2017) Social work students' reflections on gender, social justice and human rights during a short-term study abroad programme to India. International Social Work 60(1): 32-44.

Bettman JE and Prospero M (2014) A social partnership between Ghanian and US academic institutions. International Social Work 57(6): 605-617.

Brydon K, Kamasua J, Flynn C, Mason R, Au R, Ayius D and Hampson R (2014) Developing an international social work education collaboration: A partnership approach between Monash University, Australia and University of Papua New Guinea. International Social Work 57(6): 590-604. 
Cleak H and Fox M (2011) Current Australian programs for international field placements. In: Noble C and Henrickson M (eds) Social Work Field Education and Supervision Across Asia Pacific. Sydney: Sydney University Press, pp. 23-44.

Coventry L and Grace M (2013) Reciprocity and cucltural diversity: creatng successful field education placements. In: Noble C, Henrickson M and Han I Y (eds) Social Work Education: Voices for the Asia Pacific. Second Edition. Sydney: Sydney Universiy Press, pp. 303-323.

Crisp B (2009) Is there a role for 'foreigners' as social work educators? Social Work Education. 28(6): 668-677.

Crisp BR (2017) The challenges in developing cross-national social work curricula. International Social Work. 60(1): 6-18.

Dominelli L (2014) Internationalizing professional practices: The place of social work in the international arena. International Social Work. 57(3): 258267.

Engstrom D and Jones LP (2007) A broadened horizon: the value of international social work internships. Social Work Education. 26(2): 136-150.

Fox M (2016) Student isolation: the experience of distance on an international field placement. Social Work Education. DOI:

10.1080/02615479.2016.1215418.

Fox M (2017) The international field placement: a reconciliation of identity. Social Work Education. (In press).

Garrity P (2011) Australian social work students in Vietnam: the collision of cultural difference. In: Noble C and Henrickson M (eds) Social Work Field Education and Supervision across Asia Pacific. Sydney: Sydney University Press, pp. 115-144. 
Gray M and Fook J (2004) The quest for a universal social work: some issues and implications. Social Work Education. 23(5): 625-644.

Gray M (2005) Dilemmas of international social work: paradoxical processes in indigenisation, universalism and imperialism. International Journal of Social Welfare. 14: 231-238.

Hawkins CA and Knox K (2014) Educating for international social work: human rights leadership. International Social Work. 57(3): 248-257.

Healy LM (2008) International Social Work: Professional Action in an Interdependent World. Oxford: Oxford University Press.

Healy LM, Asamoah Y and Hokenstad MC (eds) (2003) Models of International Collaboration in Social Work Education. Alexandria VA: Council on Social Work Education.

Hering S and Waaldijk B (2003) Towards a 'women's history' of social work in Europe. In: Hering S and Waadijk B (eds) History of Social Work in Europe (1900-1960), Opladen: Leske + Budrich, pp. 11- 22.

Hugman R (2010) Understanding International Social Work: A Critical Analysis, London: Palgrave Macmillan.

Lyons K, Manion K and Carlsen M (2006) International Perspectives on Social Work: Global Conditions and Local Practice. Basingstoke and New York: Palgrave Macmillan.

Mathiesen SG and Lager P (2007) A model for developing international student exchanges. Social Work Education: the International Journal. 26(3): 280-291.

Matthew LE and Lough BJ (2016) Challenges social work students encounter 
in international field placements and recommendations for responsible management. Journal of Social Work Education.

http://dx.doi.org/10.1080/10437797.2016.1246268.

Nickson A, Kuruleca S and Clarke M (2009) Fijian and Australian social work learning through field education. In: Noble C, Henrickson M and Han IY (eds) Social Work Education: Voices from the Asia Pacific. Melbourne: The Vulgar Press.

Nickson A, Briscoe C, Maconachie S and Brosowski M (2011) A Vietnamese and Australian cross cultural field placement using community arts to heal and prevent child trafficking. In: Noble C and Henrickson M (eds) Social work field education and supervision across Asia Pacific. Sydney: Sydney University Press.

Panos PT, Pettys GL, Cox SE and Jones-Hart E (2004) Survey of international field education placements of accredited social work education programs. Journal of Social Work Education. 40(3): 467-478.

Panos PT (2005) A model for using videoconferencing technology to support international social work field practicum students. International Social Work. 48(6): 834-841.

Pawar M, Hanna G and Sheridan R (2004) International social work practicum in India. Australian Social Work. 57(3): 223-236.

Pettys GL, Panos PT, Cox S and Oosthuysen K (2005) Four models of international field placement. International Social Work. 48(3): 277-288.

Plummer CA and Nyang'au TO (2009) Reciprocal e-mentoring: accessible international exchanges. International Social Work. 52(6): 811-822.

Rai GS (2004) International fieldwork experience: a survey of US schools. International Social Work. 47(2): 213-226. 
Roholt RV and Fisher C (2013) Expect the unexpected: international shortterm study course pedagogies and practices. Journal of Social Work Education. 49(1): 48-65.

Rotabi KS, Gammonley D and Gamble DN (2006) Ethical guidelines for study abroad: can we transform ugly Americans into engaged global citizens? British Journal of Social Work. 36: 451-465.

Saito Y and Johns R (2009) Japanese students' perceptions of international perspectives in social work. International Social Work. 52(1): 60-71.

Sewpaul V and Jones D (2004) Global Standards for Social Work Education and Training. IASSW and IFSW, http://cdn.ifsw.org/assets/ifsw_65044-3.pdf, accessed 3/12/14.

Small E, Sharma BB and Nikolova SP (2015) A pilot study evaluating students' interest in international social work education. Social Work Education: The International Journal. 34(4): 414-427.

Tronto JC (2012) Partiality based on relational responsibilities: another approach to global ethics. Ethics and Social Welfare. 6(3): 303-316.

Wehbi S (2009) Deconstructing motivations: Challenging international social work placements. International Social Work. 52(1): 48-59.

Wehbi S (2011) Key theoretical concepts for teaching international social work. Revista de Asisenta Sociala. 10(4): 23-29. 
